\title{
Determining the link between hygroscopicity and composition for semi-volatile aerosol species
}

\author{
Joel Alroe, Luke T. Cravigan, Marc D. Mallet, Zoran D. Ristovski, Branka Miljevic, Chiemeriwo G. Osuagwu, and \\ Graham R. Johnson
}

School of Chemistry, Physics and Mechanical Engineering, Queensland University of Technology, Queensland, Brisbane, 4001, Australia

Correspondence: Zoran D. Ristovski (z.ristovski@qut.edu.au)

Received: 17 January 2018 - Discussion started: 30 January 2018

Revised: 17 June 2018 - Accepted: 6 July 2018 - Published: 24 July 2018

\begin{abstract}
Internally and externally mixed aerosols present significant challenges in assessing the hygroscopicity of each aerosol component. This study presents a new sampling technique which uses differences in volatility to separate mixtures and directly examine their respective composition and hygroscopic contribution. A shared thermodenuder and unheated bypass line are continuously cycled between an aerosol mass spectrometer and a volatility and hygroscopicity tandem differential mobility analyser, allowing real-time comparative analysis of heated and unheated aerosol properties. Measurements have been taken of both chamber-generated secondary organic aerosol and coastal marine aerosol at Cape Grim, Australia, to investigate system performance under diverse conditions. Despite rapidly changing aerosol properties and the need to restrict analysis to a narrow size range, the former experiment separated the hygroscopic influences of ammonium sulfate and two distinct organic components with similar oxygen to carbon ratios but different volatilities. Analysis of the marine aerosol revealed an external mixture of non-sea-salt sulfates and sea spray aerosol, which likely shared similar volatile fractions composed of sulfuric acid and a non-hygroscopic organic component.
\end{abstract}

\section{Introduction}

Atmospheric aerosols have important roles in air quality and the climate. These roles are strongly affected by their hygroscopicity, which represents the capacity of aerosol to adsorb water vapour from the surrounding air. Amongst other ef- fects, this water uptake promotes aqueous chemistry and can lead to the formation of cloud droplets (Seinfeld and Pandis, 2016).

Organic aerosol (OA) compounds make a large contribution to global aerosol mass (Jimenez et al., 2009), and they include a huge range of compounds with varying chemical and hygroscopic properties. Since many are semi-volatile, their relative partitioning between the particle and gas phase can be sensitive to concentration changes and local atmospheric conditions (Seinfeld and Pankow, 2003; Donahue et al., 2012). Furthermore, as their partitioning changes, they can become exposed to different phase-dependent chemical reactions. These dynamic changes complicate predictions of bulk aerosol properties.

Extensive lab-based and atmospheric studies of organic species have reported a wide range of organic hygroscopicities. For example, secondary organic aerosols (SOAs) condensed from the oxidation products of $\alpha$-Pinene have demonstrated hygroscopic growth factors ranging from 1.01 to 1.4 (Prenni et al., 2007; Duplissy et al., 2008). This range is due to the mixture of oxidation products generated by varying concentrations of precursors, oxidisers, environmental conditions, aging processes and experiment duration.

Volatility-based methods can directly separate aerosol components and have been used to investigate their independent hygroscopic contributions. Most commonly, this is achieved by passing the aerosol sample through a heated thermodenuder (TD), causing a volatile component to desorb, and examining the resulting change in properties. Until recently, this technique has been separately applied to either measurements of composition or hygroscopicity (Hong et al., 
2014; Johnson et al., 2004; Sellegri et al., 2008; Villani et al., 2013; Huffman et al., 2008). Three recent studies have combined these measurements by splitting heated samples from a TD between an aerosol mass spectrometer (AMS) and a cloud condensation nuclei (CCN) counter (Cain and Pandis, 2017; Cerully et al., 2015; Hildebrandt Ruiz et al., 2015).

Cain and Pandis (2017) and Hildebrandt Ruiz et al. (2015) examined chamber-generated SOA from $\alpha$-Pinene and toluene respectively, while Cerully et al. (2015) performed atmospheric measurements of rural aerosol from the southeastern United States. Across these three cases, a clear relationship between hygroscopicity and oxidation level (often measured as an oxygen to carbon ratio, $\mathrm{O}: \mathrm{C}$ ) could not be established. In addition, the least volatile organic compounds were shown to have the lowest hygroscopicity, which contrasts with many previous studies. Cain and Pandis (2017) found that low-volatility compounds typically had high $\mathrm{O}: \mathrm{C}$ ratios, while Hildebrandt Ruiz et al. (2015) observed conflicting trends. Cerully et al. (2015) did not report either trend for the $\mathrm{O}: \mathrm{C}$ ratio but found correlation between low volatility and high average carbon oxidation state $\left(\overline{\mathrm{OS}}_{\mathrm{C}}\right)$, an alternate measure of oxidation level (Kroll et al., 2011). In short, each study highlighted the complexity of organic hygroscopicity and the importance of volatility-based methods in distinguishing their competing contributions.

The above techniques for measuring bulk aerosol properties are convenient to implement; however generally they do not examine size-dependent variations in hygroscopicity or the presence of external mixing. Although water uptake is typically more strongly influenced by particle size than by composition (Dusek et al., 2006), the role of composition becomes highly significant near the critical diameter for cloud droplet activation, and a large proportion of the aerosol number concentration is often centred there (Wex et al., 2010). The critical diameter is sensitive to changes in aerosol hygroscopicity, so the composition of aerosol at or near the critical diameter can significantly affect the number concentration of available CCN (Andreae and Rosenfeld, 2008; Mallet et al., 2017). Similarly, bulk analysis of externally mixed aerosol can be confounded by the competing hygroscopic influences of aerosol from different sources. Measurement techniques which separate these mixtures can assist with source apportionment and investigation of each aerosol type.

In this article, we describe a novel real-time sampling system which couples an AMS to a volatility and hygroscopicity tandem differential mobility analyser (VH-TDMA) and discuss how this combined approach provides valuable insight into the properties of the semi-volatile component.

\section{Methodology}

\subsection{Sampling system design}

The AMS provides real-time non-refractory chemical speciation and, while it is most commonly used to sample bulk (total) aerosol composition, it is also capable of sizedependent measurements derived from the particle time of flight (PTOF). A full explanation of its design is given by Drewnick et al. (2005). For this study, a compact time-offlight AMS has been used, which generates spectra with unit mass resolution and offers maximum sensitivity for aerosol with vacuum aerodynamic diameters $\left(d_{\mathrm{va}}\right)$ between 100 and $600 \mathrm{~nm}$ (Liu et al., 2007; Takegawa et al., 2009). Detection limits for each species are calculated as 3 times the standard deviation of their background concentration, observed when sampling particle-free air through a high-efficiency particle filter (DeCarlo et al., 2006). This accounts for the instrument's background signal from stray ions and electronic noise. Uncertainties are given as the larger value of either the detection limit or the species-dependent measurement accuracy of the AMS. These accuracy estimates encompass uncertainties in the ionisation efficiencies, particle collection efficiencies and the inlet flow rate and are commonly estimated at $\pm 37 \%$ for organics, $\pm 35 \%$ for $\mathrm{SO}_{4}$ and $\mathrm{Chl}$, and $\pm 33 \%$ for $\mathrm{NO}_{3}$ and $\mathrm{NH}_{4}$ (Bahreini et al., 2008).

The VH-TDMA measures aerosol volatility and hygroscopicity under subsaturated humidities. The function of our instrument has been explained in other papers (Johnson et al., 2005; Fletcher et al., 2007). In short, aerosol of a preselected narrow size range is heated in a compact TD with a maximum temperature of $500^{\circ} \mathrm{C}$ and residence time of $3 \mathrm{~s}$. The sample then passes to two scanning mobility particle sizers (labelled V-SMPS and H-SMPS), with a humidified stage preceding the H-SMPS. These measure the mobility diameter $\left(d_{\mathrm{m}}\right)$ change due to loss of volatile material and subsequent hygroscopic growth, respectively. Particle hygroscopicity is reported as a hygroscopic growth factor (HGF), representing the relative increase in particle diameter after humidification compared to the dry diameter.

To obtain simultaneous hygroscopic and compositional measurements, the two instruments (AMS and VH-TDMA) have been coupled together through a combined flow system, shown in Fig. 1. After passing through a shared inlet, the aerosol is dried to a relative humidity (RH) of approximately $30 \%$ using a membrane dryer (Nafion MD-700) or a silica gel diffusion dryer. To assist electrical mobility-based measurements in the VH-TDMA, a well-defined charge distribution is applied to the sample with a $\mathrm{Kr}-85$ neutraliser (TSI model 3012A). The RH and temperature of this dried aerosol flow is measured with a humidity probe (Rotronic HC2-WIN-USB) which is recessed in a sealed T-junction to avoid disrupting the sample flow. Since air exchange in the recessed region is diffusion limited, the probe provides an 
Sampling mode 1

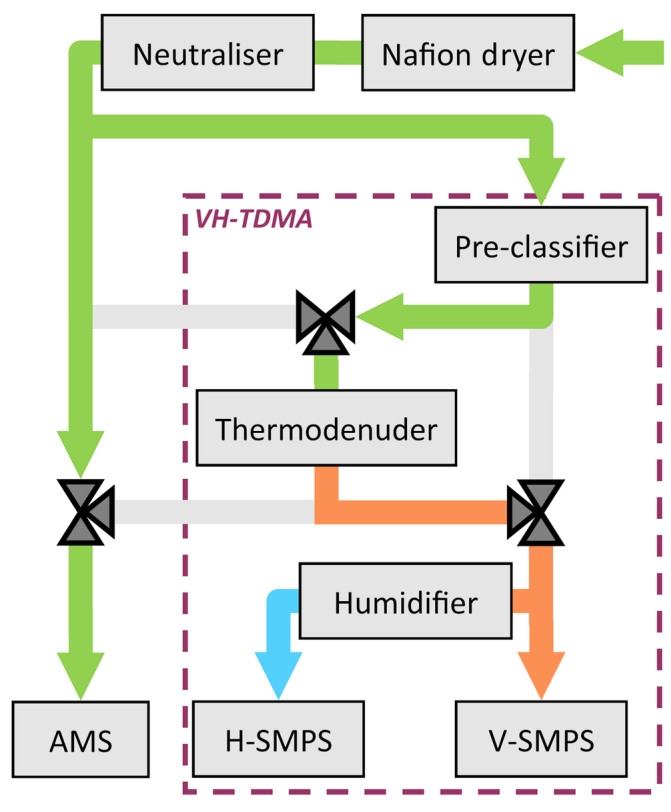

Legend
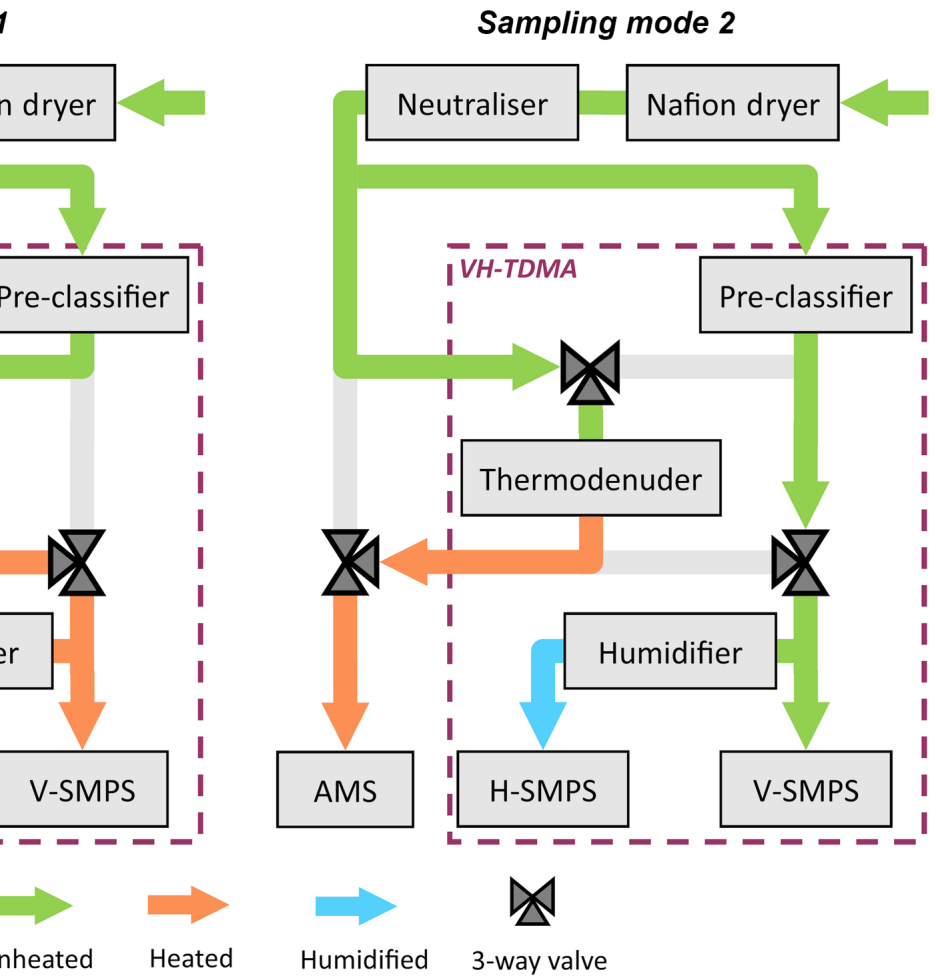

Figure 1. Schematics of the VH-TDMA-AMS sampling system, demonstrating the alternating flow paths used for consecutive samples.

estimate of mean inlet $\mathrm{RH}$ rather than precise time-resolved measurements.

After the neutraliser, the flow is evenly split between the TD and an unheated bypass line. A series of fast-acting solenoid valves are used to direct these two sampling flows so that one instrument measures heated aerosol, while the other receives the unheated sample. Under normal sampling conditions, the flow paths are switched between the instruments every $3 \mathrm{~min}$, allowing them both to perform a continual series of consecutive heated and unheated measurements. Changes in HGF, composition and particle diameter between these alternating samples can be attributed to the removal of the semi-volatile species. The switching process is automated using control software developed in LabView. This software also manages the VH-TDMA preselected aerosol diameter, TD temperature and humidifier settings. These can be progressively stepped through a range of set values to investigate size dependencies, volatility distributions or to reveal any deliquescence or efflorescence transitions between dry and aqueous particle phases.

The two instruments sample at different flow rates. To avoid flow-rate-dependent variations in transmission efficiencies and temperature fluctuations in the TD, flow rates of $1 \mathrm{~L} \min ^{-1}$ are maintained in both sampling lines. Since this is lower than the combined flow rate required for the V- and $\mathrm{H}$ SMPS, mass flow controllers provide supplementary filtered air to these components and their measured particle concen- trations are corrected for this dilution. Conversely, since the AMS requires only a $0.1 \mathrm{~L} \mathrm{~min}^{-1}$ sample flow, an additional $0.9 \mathrm{~L} \mathrm{~min}^{-1}$ of sample flow is maintained by a mass flow controller and vacuum supply connected near the AMS inlet. With the exception of a few short flexible connections using conductive silicon, stainless steel tubing has been used throughout the sampling system to avoid siloxane-based contamination of the hygroscopic and compositional measurements (Timko et al., 2009).

\subsection{Thermal volatility measurements}

Desorption rates within a TD are kinetically limited, particularly at high concentrations, and aerosol may not reach thermodynamic equilibrium within the TD (Riipinen et al., 2010). This can lead to underrepresentations of particle volatility (An et al., 2007) and requires considerable analysis to determine effective saturation concentrations. Future studies may extend this approach to quantify the volatility of each desorbed component; however, in this study, the TD has been operated at a single temperature $\left(120^{\circ} \mathrm{C}\right)$ and used simply for component separation. In line with this, the fraction desorbed within the TD has been referred to as the semi-volatile component, while the remainder has been termed the less-volatile component. This scheme implicitly assumes complete separation of the two components. The TD used in this study had a short residence time and no cooling stage; therefore it is possible that some residual proportion of the semi-volatile 
component remained (or recondensed) in the particle phase. As a further complication, several studies have suggested that heating the aerosol may promote chemical change, leading to either formation (Huffman et al., 2009; Denkenberger et al., 2007) or decomposition of oligomers (Hall and Johnston, 2012). So, any change in aerosol properties after heating may be due to removal of a semi-volatile component, temperature-dependent chemical change of the less volatile component, or both factors. This is an inherent limitation of most thermal sampling processes, including the AMS, and requires consideration when examining the influence of desorbed species.

\subsection{Size-resolved composition}

The AMS is commonly used to assess the bulk composition of non-refractory aerosol smaller than $1 \mu \mathrm{m}$. However, when sampling aerosol with size-dependent composition, this bulk analysis becomes dominated by aerosol with larger diameter and mass. This study primarily focused on aerosol with $d_{\mathrm{m}}=100 \mathrm{~nm}$, as this is both sufficiently small for composition to have a significant influence on $\mathrm{CCN}$-forming potential and large enough to be within the peak sensitivity range of the AMS. Therefore, for samples with strongly sizedependent composition, PTOF-AMS measurements were integrated over a range of $d_{\mathrm{va}}$, which best represented aerosol at the preselected $d_{\mathrm{m}}$ used by the VH-TDMA. This range was affected by particle density $\left(\rho_{\mathrm{p}}\right)$ and the Jayne shape factor $(S)$, as given by the following calculation (DeCarlo et al., 2004):

$d_{\mathrm{va}}=\frac{\rho_{\mathrm{p}}}{\rho_{0}} S \times d_{\mathrm{m}}$,

where $\rho_{0}$ is the unit density. For heated measurements, this PTOF $d_{\mathrm{va}}$ range was shifted downwards in proportion to the $d_{\mathrm{m}}$ reduction observed with the VH-TDMA. AMS particle transmission efficiency decreases for diameters below $d_{\mathrm{va}}=100 \mathrm{~nm}$, reaching approximately $0 \%$ transmission at $40 \mathrm{~nm}$. Since the chamber-based measurements discussed in Sect. 3.1 required PTOF data from this diameter range, a linear correction factor was applied to account for transmission losses (Knote et al., 2011).

While this use of PTOF data provides a composition that is more directly relevant to the VH-TDMA measurements, it encompasses a reduced fraction of the overall aerosol mass concentration and does not benefit from as much signal averaging as is available for bulk analysis. This is particularly exacerbated during periods of low mass concentration or rapid changes in aerosol properties. As demonstrated in Sect. 3.1, the time resolution must be carefully chosen to allow sufficient signal averaging while still capturing transient changes in the aerosol.

\subsection{Hygroscopic analysis}

The hygroscopicity of small particles is reduced by the Kelvin effect, which causes water activity $\left(a_{\mathrm{w}}\right)$ at the droplet-air interface to increase with particle curvature. To account for this, the measured HGFs can be re-expressed in terms of the hygroscopicity parameter $(\kappa)$, using $\kappa$-Köhler theory (Petters and Kreidenweis, 2007):

$\frac{\mathrm{RH} / 100}{\exp \left(\frac{4 \sigma M_{\mathrm{w}}}{R T \rho_{\mathrm{w}} D_{\mathrm{d}} \mathrm{HGF}}\right)}=\frac{\mathrm{HGF}^{3}-1}{\mathrm{HGF}^{3}-(1-\kappa)}$,

where RH is the relative humidity set in the H-SMPS, $\sigma$ is the droplet surface tension (assumed to be equivalent to pure water, $\sigma_{\mathrm{w}}=0.072 \mathrm{~J} \mathrm{~m}^{-2}$ ), $M_{\mathrm{w}}$ is the molecular weight of water, $R$ is the universal gas constant, $T$ is the temperature, $\rho_{\mathrm{w}}$ is the density of water and $D_{\mathrm{d}}$ is the dry particle diameter. The $\kappa$ values can then be reverted to Kelvin-corrected HGFs $\left(\mathrm{HGF}_{\text {corr }}\right.$ ) by setting $a_{\mathrm{w}}$ equal to RH divided by 100 :

$\frac{1}{a_{\mathrm{w}}}=1+\frac{\kappa}{\mathrm{HGF}_{\text {corr }}^{3}}$.

After excluding the effect of droplet curvature, the compositional influence on hygroscopicity can be investigated in detail. The hygroscopicity of internally mixed aerosol is commonly estimated using the following volume-weighted model (Stokes and Robinson, 1966):

$\mathrm{HGF}_{\text {total }}^{3}=\sum_{i} \varepsilon_{i} \mathrm{HGF}_{i}^{3}$,

where $\varepsilon_{i}$ and $\mathrm{HGF}_{i}$ are the volume fraction and independent HGF contribution of each component. If the components have substantially different volatilities, these parameters can be directly determined from VH-TDMA measurements. Otherwise assumed HGF contributions are used and $\varepsilon_{i}$ is derived from the corresponding mass concentrations $\left(m_{i}\right)$ and densities $\left(\rho_{i}\right)$ of each component:

$\varepsilon_{i}=\frac{m_{i} / \rho_{i}}{\sum_{i} m_{i} / \rho_{i}}$.

\subsection{Aerosol transmission efficiencies}

The two sampling lines offer different transmission efficiencies due to variations in tubing geometry, an additional solenoid valve on the TD line and losses associated with the TD itself. Diffusional losses in the TD have been reduced by omitting the cooling section. When sampling at high aerosol loading, this may cause recondensation of volatile species onto the aerosol as it cools at the outlet. However, negligible recondensation is expected for most atmospheric samples (Saleh et al., 2011). The remaining differences in transmission efficiency have been quantified by examining size- and temperature-dependent changes in aerosol concentration between the two flow paths. 


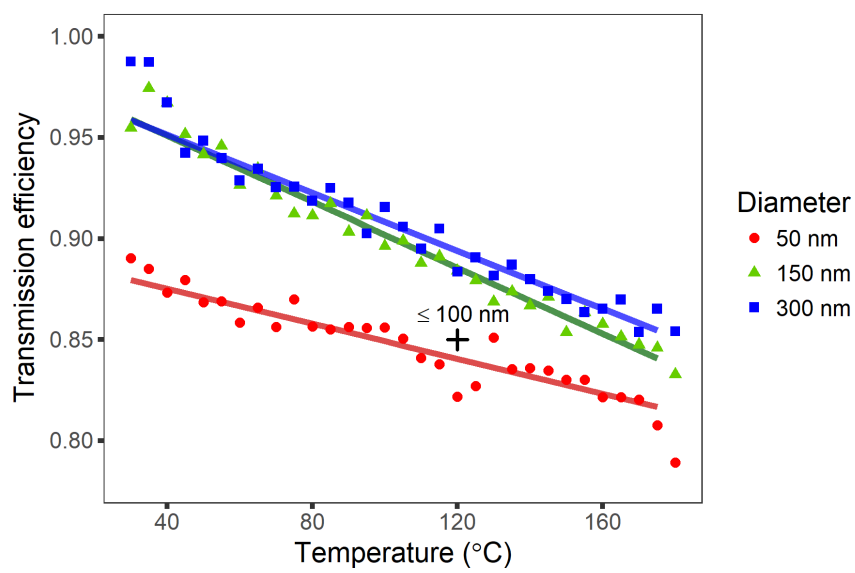

Figure 2. Size- and temperature-dependent aerosol transmission rates of the TD sampling line compared to the unheated line for AS aerosol. The value used in this study for aerosol $\leq 100 \mathrm{~nm}$ has been marked for comparison.

Ammonium sulfate (AS) aerosol was generated with a nebuliser (Mesa Labs, 6-jet Collison). The aerosol was dried, neutralised and sampled at three preselected sizes: $d_{\mathrm{m}}=50$, 150 and $300 \mathrm{~nm}$. The humidifier and H-SMPS were replaced with a condensation particle counter (CPC; TSI model 3772) and a suitable bypass flow to maintain normal sampling flow rates throughout the system. From each sampling line, measurements were made with the TD at room temperature to examine differences in tubing and solenoid valves. The TD temperature was then progressively increased in $5^{\circ} \mathrm{C}$ increments up to the volatilisation point of $\operatorname{AS}\left(180^{\circ} \mathrm{C}\right.$ at $50 \mathrm{~nm}$ in this system) to quantify thermophoretic losses.

Figure 2 displays the relative transmission efficiency of the TD line compared to the unheated line. For diameters of $150 \mathrm{~nm}$ and above, path-dependent losses of less than $5 \%$ were observed at room temperature. This increased to over $12 \%$ at $50 \mathrm{~nm}$. In addition, transmission efficiency decreased linearly with increasing temperature for all sizes. Based on these results, a constant correction factor has been applied to all size-resolved AMS mass concentrations in this study, assuming a mean $85 \%$ relative transmission efficiency for aerosol of $d_{\mathrm{m}} \leq 100 \mathrm{~nm}$ at $120^{\circ} \mathrm{C}$. This reduces bias between the two sampling lines and isolates the compositional changes caused by removal of volatile species.

\subsection{Smog chamber sampling}

A system test was conducted under controlled conditions to examine correlation between the two instruments and ensure that meaningful conclusions could be drawn. Measurements were performed using AS-seeded secondary organic aerosol (SOA), generated in a temperature-controlled, $8 \mathrm{~m}^{3}$ Teflon@ smog chamber. To minimise wall losses, this chamber has not been fitted with any mixing fans. During all chamber preparations, purified air was generated with a zero-

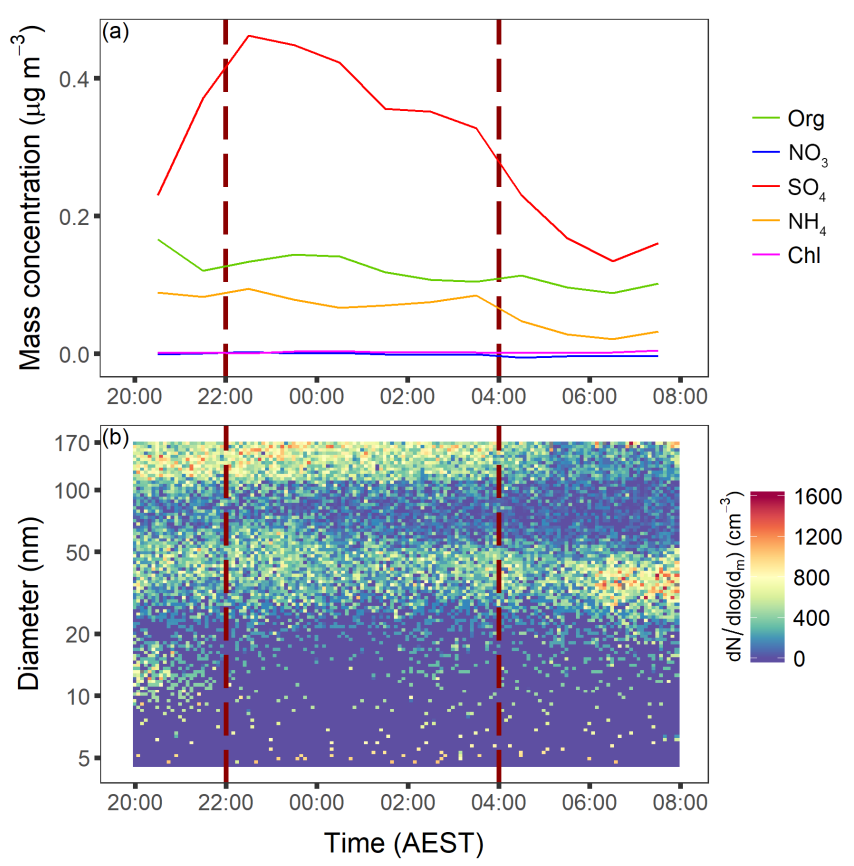

Figure 3. (a) Mass concentrations of major compositional species and (b) size distributions of particle number concentration observed at the Cape Grim site on 2-3 March 2015. Dashed lines delimit a $6 \mathrm{~h}$ period of relatively stable baseline sampling conditions.

air generator (Aadco, model 737-13). Type 2 laboratorygrade deionised water was used in all solutions and in humidifying the chamber.

The chamber was cleaned by first being flushed with a $1 \mathrm{ppm}$ concentration of $\mathrm{O}_{3}$ in purified air until particle number concentrations fell below $100 \mathrm{~cm}^{-3}$. The UV lights were turned on for $10 \mathrm{~min}$ to promote particle formation, and the chamber was again flushed with ozone-free purified air until particle numbers decreased below $100 \mathrm{~cm}^{-3}$. The chamber was then prepared by successively passing water vapour, gaseous nitrous acid (HONO), N-butanol and $\alpha$-Pinene into the chamber using a $15 \mathrm{~L} \mathrm{~min}^{-1}$ carrier flow of purified air. Water vapour was flushed into the chamber from a heated glass flask of deionised water until a relative humidity of $50 \%$ was achieved. The HONO was generated by adding a $0.15 \mathrm{M}$ aqueous solution of $\mathrm{NaNO}_{2}$ (Sigma-Aldrich) to 1.1 M sulfuric acid (Thermo Fisher Scientific) and was introduced over a $20 \mathrm{~min}$ period. $1 \mu \mathrm{L}$ of N-butanol (D9, $98 \%$, Sigma-Aldrich) and $\alpha$-Pinene (Sigma-Aldrich) were each vaporised in separate heated glass bulbs. The former acted as a tracer, allowing $\mathrm{OH}$ concentrations to be monitored with a chemical ionisation time-of-flight mass spectrometer (Barmet et al., 2012). A polydisperse distribution of AS seed particles were generated by nebulising an $0.07 \mathrm{M}$ aqueous AS solution using laboratory compressed air filtered through a high-efficiency particulate air filter. These were injected into the chamber until particle number concentrations reached $10^{4} \mathrm{~cm}^{-3}$ with a geometric mean diameter of $94 \mathrm{~nm}$. 
Table 1. Parameters used in the compositional model of marine semi-volatile hygroscopicity.

\begin{tabular}{lll}
\hline Component & Density $\left(\mathrm{g} \mathrm{cm}^{-3}\right)$ & HGF contribution \\
\hline OA & $1.2 \pm 0.1^{\mathrm{a}}$ & $1.0 \pm 0.1$ \\
Sulfuric acid & $1.83 \pm 0.01^{\mathrm{b}}$ & $1.95 \pm 0.05^{\mathrm{c}}$ \\
\hline
\end{tabular}

${ }^{\mathrm{a}}$ Ault et al. (2013); Hersey et al., 2009). ${ }^{\mathrm{b}}$ Washburn (1926);

c Xiong et al. (1998).

The chamber was then irradiated by $20160 \mathrm{~W}$ UV lamps and sampling was conducted over a $4 \mathrm{~h}$ period.

VH-TDMA measurements were performed on $100 \mathrm{~nm}$ aerosol with a $6 \mathrm{~min}$ time resolution $(3 \mathrm{~min}$ per sampling path). The TD was set to $120^{\circ} \mathrm{C}$ to desorb organic compounds with higher volatility than AS. A Nafion dryer was used to maintain the inlet RH at $32.6 \pm 0.3 \%$ throughout the experiment and the H-SMPS was humidified to $88 \%$ RH. Initial gas-phase concentrations within the chamber were $35 \mathrm{ppb} \alpha$-Pinene, $0.042 \mathrm{ppm} \mathrm{NO}_{x}$ and approximately $1.5 \times 10^{7}$ molecules $\mathrm{cm}^{-3}$ of $\mathrm{OH}$, at a relative humidity of $56 \%$. However, due to time constraints, UV irradiation and sampling commenced immediately after aerosol injection was completed, so initially the chamber may not have been uniformly mixed.

\subsection{Remote coastal measurements}

To investigate the suitability of the combined system for atmospheric sampling, it was deployed to the Cape Grim Baseline Air Pollution Station for a 2-week measurement campaign in March 2015. This remote site on the northwestern coast of Tasmania, Australia, frequently receives strong westerly winds carrying marine aerosol with negligible terrestrial or anthropogenic influences. From 22:00 on 2 March, these baseline conditions were observed for an $8 \mathrm{~h}$ period, with mean particle number concentrations of $400 \pm 60 \mathrm{~cm}^{-3}$ for aerosol diameters above $10 \mathrm{~nm}$. This period was accompanied by significantly increased sulfate-related mass concentration and a pronounced bimodal particle number size distribution (Fig. 3), consistent with cloud-processed marine aerosol (Hoppel et al., 1986). The final $2 \mathrm{~h}$ of baseline sampling was accompanied by a pronounced decrease in sulfateand ammonium-related signal and a decrease in particle number concentration, suggesting a change in the air mass and associated aerosol properties. For this reason, analysis has been focused on the initial $6 \mathrm{~h}$, which exhibited the most consistent properties.

To account for the low aerosol concentrations, aerosol properties were averaged over this $6 \mathrm{~h}$ period and the resulting mean values were used for all further analysis. Likewise, uncertainties have been determined from standard deviations in the means. The sampling inlet RH was consistently dried with a diffusion dryer to below $30 \%$ and the humidifier was maintained at $90 \%$ RH. Sampling was conducted us-
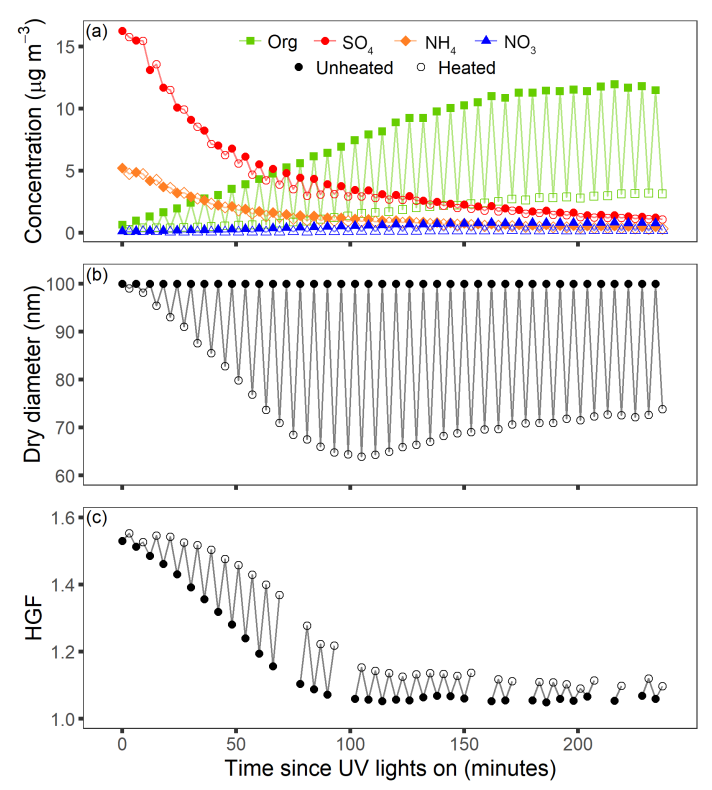

Figure 4. Alternating direct measurements of unheated and heated aerosol properties during $4 \mathrm{~h}$ of $\alpha$-Pinene SOA formation on AS seed particles, demonstrating decreases in (a) bulk non-refractory mass concentration and (b) dry particle diameter, and (c) the corresponding increases in HGF after removal of a semi-volatile fraction at $120^{\circ} \mathrm{C}$. Gaps in the HGF data are due to faulty H-SMPS measurements which have been discarded.

ing the same preselected diameter and TD temperature as in the chamber-based experiment (i.e. $100 \mathrm{~nm}, 120^{\circ} \mathrm{C}$ respectively).

\section{Results and validation}

\subsection{Chamber-generated aerosol}

A characteristic example of the alternating heated and unheated measurements obtained from both instruments is given in Fig. 4, showing the impact of an increasing SOA component on bulk aerosol composition, volatility and water uptake during the smog chamber experiment. Measurements commenced immediately after injecting the AS seeds and there was no active mixing mechanism within the chamber. In light of this, the initial rapid decrease in $\mathrm{SO}_{4}$ concentrations suggests that the chamber was not well mixed during the first $40 \mathrm{~min}$ of sampling. After this point, the total mass loading and mode diameter of the number size distributions progressively increased in response to SOA formation (Figs. S1 and S2 in the Supplement).

Compositional measurements of the seeded SOA indicated a strong size dependence, with the AS mass distributed around a mean $d_{\mathrm{va}}$ of approximately $500 \mathrm{~nm}$, while the SOA component progressively dominated at 100 $200 \mathrm{~nm}$ (Fig. 5a). Since the size distribution of each species 
Table 2. Hygroscopicity of volatility-resolved fractions observed in externally mixed marine aerosol.

\begin{tabular}{lllll}
\hline Classification & $\begin{array}{l}\text { Semi-volatile } \\
\text { volume fraction }\end{array}$ & $\begin{array}{l}\text { Semi-volatile } \\
\text { HGF }\end{array}$ & Heated HGF & $\begin{array}{l}\text { Total unheated } \\
\text { HGF }\end{array}$ \\
\hline Nss sulfate & $0.12 \pm 0.02$ & $1.2 \pm 0.3^{*}$ & $1.61 \pm 0.02$ & $1.57 \pm 0.01$ \\
SSA & $0.12 \pm 0.02$ & $1.2 \pm 0.3^{*}$ & $2.01 \pm 0.05$ & $1.90 \pm 0.04$ \\
\hline
\end{tabular}

* Derived from VH-TDMA measurements of nss sulfate aerosol.
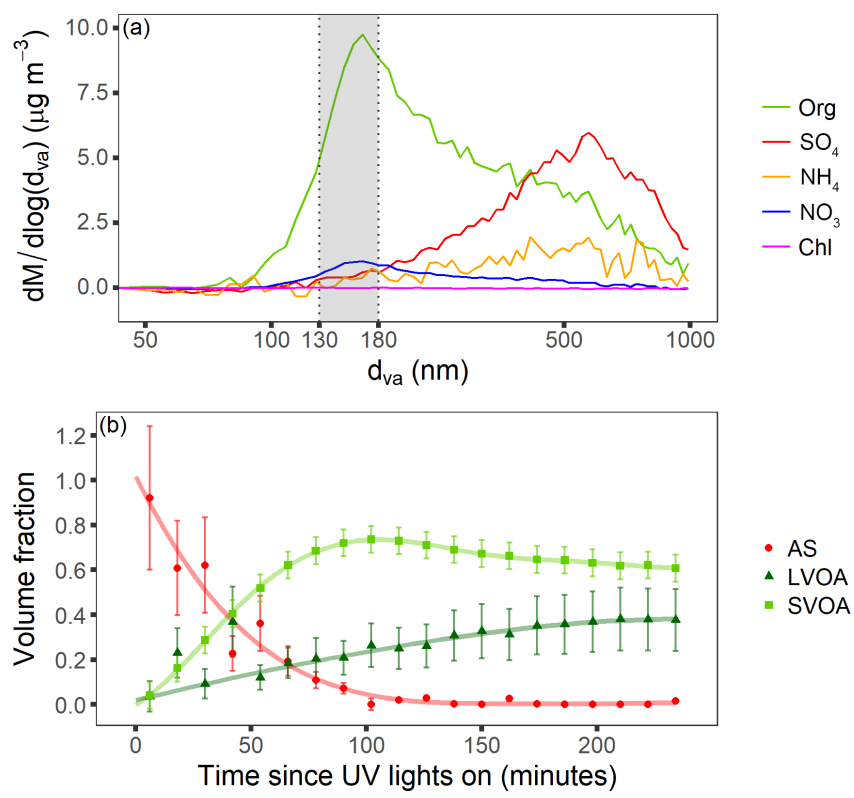

Figure 5. (a) Mean size distribution of the major compositional species measured by the AMS, observed over $4 \mathrm{~h}$ of SOA condensation and ripening. The shaded region represents the approximate $d_{\mathrm{va}}$ range for particles with $d_{\mathrm{m}}=100 \mathrm{~nm}$. (b) Relative volume contributions of AS, LVOA and SVOA for aerosol in the selected $d_{\mathrm{va}}$ range. The curves are fitted splines to guide the eye.

did not change substantially over time, further compositional analysis was restricted to diameters in the range $130<d_{\mathrm{va}}<180 \mathrm{~nm}$. This range was selected to reflect varying proportions of internally mixed SOA and AS with densities of 1.3 and $1.78 \mathrm{~g} \mathrm{~cm}^{-3}$, respectively (Chen and Hopke, 2009).

While these size limits ensured that the compositional analysis was directly relevant to the $d_{\mathrm{m}}$ used by the $\mathrm{VH}$ TDMA, it reduced the sensitivity of the AMS measurements in two ways. Firstly, this diameter range represented a comparatively low proportion of the total particle mass, decreasing the signal-to-noise ratio of the measurements. Secondly, by using only a subset of PTOF measurements rather than the bulk aerosol measurements, less signal averaging was applied to each sample, increasing the variability of the measurements. To account for this, the size-resolved composition was averaged to a 12 min time resolution and the resulting time series has been provided in the Supplement (Fig. S3).
This resolution was sufficiently fast to observe the SOA fraction progressively growing to dominate the mass composition at $100 \mathrm{~nm}$ while ensuring that the compositional measurements were sufficiently stable to be useful for hygroscopic predictions.

At this time resolution, the estimated detection limits were $0.123,0.012,0.023,0.245$ and $0.023 \mu \mathrm{g} \mathrm{m}^{-3}$ for organics, $\mathrm{NO}_{3}, \mathrm{SO}_{4}, \mathrm{NH}_{4}$ and $\mathrm{Chl}$ respectively. While these values are considerably higher than when using bulk aerosol measurements, a large proportion of the PTOF measurements remained above these limits, with two notable exceptions. Chl concentrations were consistently negligible and since there was no source of this species, it has been disregarded in the subsequent analysis. In addition, the $\mathrm{NH}_{4}$ background signal increased by an order of magnitude when averaged over the narrow PTOF range. $\mathrm{NH}_{4}$ often exhibits higher variability than most other species. Also, immediately prior to measuring the background signal, the AMS had been sampling from the chamber during injection of the AS seeds and so some residual AS may have remained in the instrument during the filtered background measurements. Ultimately the cause of this variable signal has not been established. In any case, $\mathrm{NH}_{4}$ represented a significant fraction of the injected AS aerosol mass and therefore it was not feasible to exclude its contribution. Instead, the $\mathrm{NH}_{4}$ mass concentrations were approximated with a linear fit to the $\mathrm{NH}_{4}$ PTOF measurements.

A strong correlation was observed between the organic and $\mathrm{NO}_{3}$ signals indicating the secondary formation of organonitrates or nitric acid from $\mathrm{NO}_{x}$-based reactions. To simplify the analysis, these species were summed to give the mass concentration of OA. Likewise, the $\mathrm{SO}_{4}$ and fitted $\mathrm{NH}_{4}$ concentrations were combined to give size-resolved AS concentrations throughout the experiment.

As shown in Fig. 5b, during the first $100 \mathrm{~min}$ of the experiment, a semi-volatile organic component rapidly formed, increasing particle volatility and reducing the HGF of the unheated aerosol from 1.5 to $<1.1$ (Fig. 4c). After this point, there was no significant change to HGFs and volatility gradually decreased. Figure $5 \mathrm{~b}$ also shows that the heated aerosol composition revealed an increasing proportion of less volatile organic compounds which did not desorb at $120^{\circ} \mathrm{C}$. For convenience, these two semi-volatile and less-volatile organic components have been labelled SVOA and LVOA, respectively. 


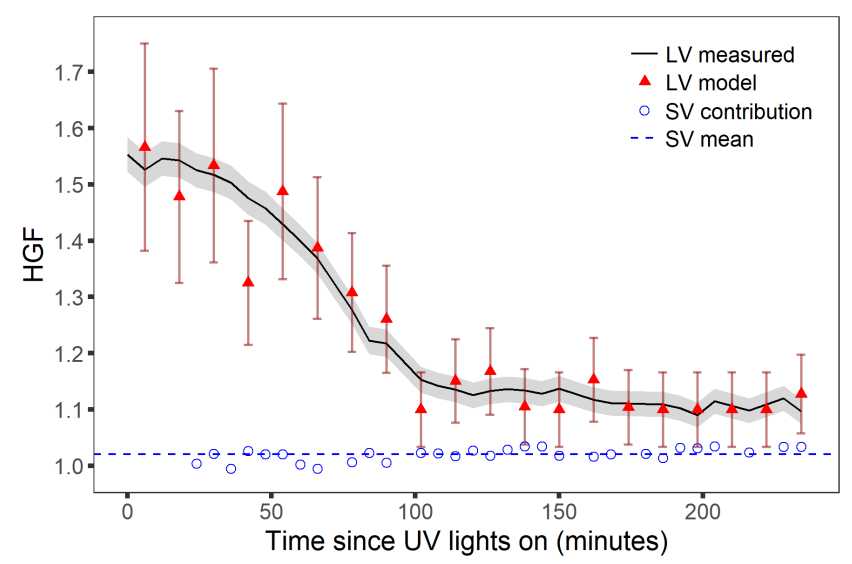

Figure 6. Comparison between measured (black line) and modelled (triangles) HGFs for the lower volatility component during SOA formation. The shaded region shows $\pm 2 \%$ uncertainty in H-SMPS measurements, while error bars represent composition-dependent uncertainties for this model. The derived HGF of the semi-volatile component is shown for contrast.

The unit mass resolution parameterisation given by Canagaratna et al. (2015) was used to calculate elemental ratios of oxygen to carbon $(\mathrm{O}: \mathrm{C})$, averaged across all diameters with the assumption that these ratios would be size invariant. The OA concentrations were mostly stable and well resolved during the final $30 \mathrm{~min}$ of the experiment. Based on this period, both the LVOA and SVOA components exhibited similar $\mathrm{O}: \mathrm{C}$ ratios of $0.43 \pm 0.16$ and $0.45 \pm 0.16$, respectively.

To confirm the predictive power of this combined sampling approach, the measured HGFs of the heated sample were compared against the composition-based model defined in Eq. (4). Assumed densities of $1.3 \mathrm{~g} \mathrm{~cm}^{-3}$ (Duplissy et al., 2008) and $1.78 \mathrm{~g} \mathrm{~cm}^{-3}$ were used for $\alpha$-Pinene SOA and AS, respectively. AS calibration measurements indicated that the HGF of AS at $88 \%$ RH was $1.58 \pm 0.03$, after correcting for residual water in the particle phase during preselection. The hygroscopic contribution of the low-volatility SOA component was determined using the $\mathrm{O}: \mathrm{C}$ parameterisation proposed by Massoli (2010), giving an $\mathrm{HGF}_{\mathrm{LVOA}}$ of $1.1 \pm 0.2$. This value agrees well with a range of $\alpha$-Pinene HGFs reported in other studies (Varutbangkul et al., 2006; Virkkula et al., 1999; Prenni et al., 2007; Cocker III et al., 2001). Applying these AS and LVOA parameters to the compositionbased model produced HGFs which closely matched the direct VH-TDMA measurements of the heated sample, as seen in Fig. 6.

Having established agreement between the instruments, Eq. (4) was adapted to determine the hygroscopic contribution of the SVOA using measurements of particle diameter (d) and HGF:

$\mathrm{HGF}_{0}^{3}=\left(\frac{d_{0}^{3}-d_{\mathrm{TD}}^{3}}{d_{0}^{3}}\right) \mathrm{HGF}_{\mathrm{SVOA}}^{3}+\left(\frac{d_{\mathrm{TD}}}{d_{0}}\right)^{3} \mathrm{HGF}_{\mathrm{TD}}^{3}$,

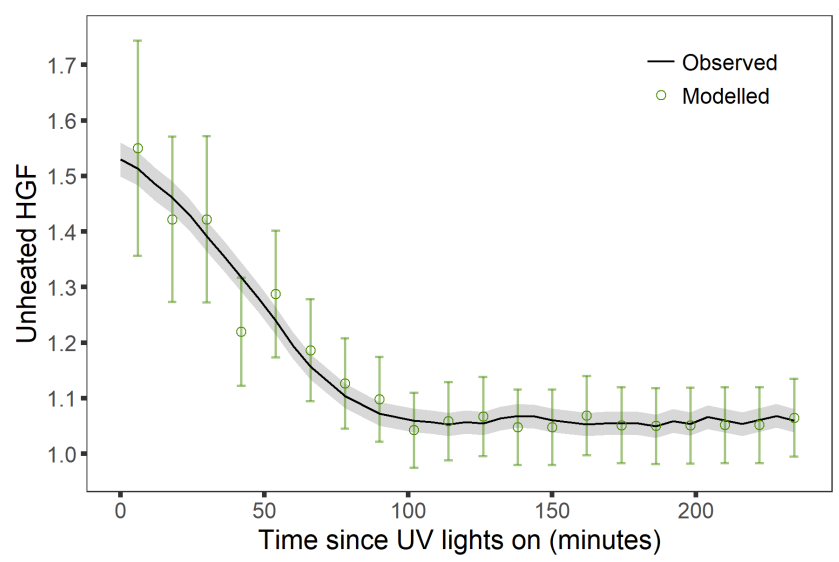

Figure 7. Observed and predicted hygroscopicity of unheated, internally mixed $\alpha$-Pinene SOA and AS aerosol during $4 \mathrm{~h}$ of SOA formation. The shaded region shows $\pm 2 \%$ uncertainty in H-SMPS measurements, while error bars represent composition-dependent uncertainties for this model.

where subscript 0 and TD refer to the unheated and heated samples, respectively. This use of direct VH-TDMA measurements avoided any dependence on an assumed SVOA density. The first $20 \mathrm{~min}$ of the experiment was excluded due to low SVOA concentrations which caused unreliable HGF estimates. The remaining data support a stable mean HGF $_{\text {SVOA }}$ of $1.02 \pm 0.02$ (Fig. 6). This low value mirrors other studies of semi-volatile organics (Meyer et al., 2009; Raatikainen et al., 2010) and is within the range of $\alpha$ Pinene HGFs observed by Prenni et al. (2007) and Denjean et al. (2015).

In the preceding steps of this analysis, the HGF contributions and volume fractions for all three components (AS, SVOA and LVOA) were established. Using these parameters and the same additive model, the hygroscopicity of the unheated aerosol was calculated. The results closely agreed with the observed HGFs (Fig. 7), confirming that the derived parameters accurately describe the aerosol properties throughout the experiment.

\subsection{Remote coastal measurements}

During the initial $6 \mathrm{~h}$ of sampling under baseline conditions at Cape Grim, mass concentrations were very low and there was little evidence of size-dependent composition. Therefore, to provide better statistics, bulk aerosol composition has been used in this analysis. The non-refractory aerosol mass was dominated by sulfate $(65.8 \%)$, ammonium $(12.9 \%)$ and organic compounds (20.7\%) (Fig. 8), while the nitrate- and chloride-related signals were consistently below their respective detection limits. Of this non-refractory mass $49.5 \%$ was desorbed at $120^{\circ} \mathrm{C}$, including the entire non-refractory organic fraction. This organic volatility was reflected in the $\mathrm{O}: \mathrm{C}$ ratio of 0.24 , which is consistent with semi-volatile 


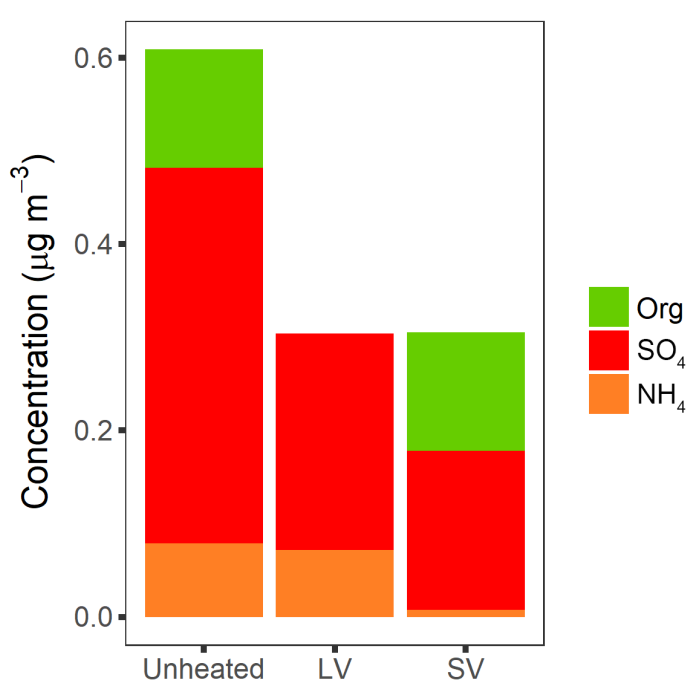

Figure 8. Contribution of sulfates, ammonium and non-refractory organic compounds to the total, semi-volatile and low-volatility fractions of marine aerosol at Cape Grim.

oxygenated OA observed in other AMS studies (Jimenez et al., 2009; Raatikainen et al., 2010). Of the sulfates $42 \%$ was desorbed, despite being well below the volatilisation temperature of ammonium sulfate. In contrast, the ammonium signal showed minimal volatility, indicating that a significant proportion of the sulfate was in the form of sulfuric acid and ammonium bisulfate. This is further supported by an ammonium to sulfate molar ratio of $1.03 \pm 0.04$ in the unheated aerosol.

Humidification of the $100 \mathrm{~nm}$ preselected aerosol frequently produced a bimodal particle size distribution, indicating that the aerosol was externally mixed. The dominant proportion exhibited a mean HGF of $1.57 \pm 0.01$, while a second aerosol type had a mean HGF of $1.90 \pm 0.04$. These growth factors are characteristic for non-sea-salt (nss) sulfate-dominated particles and sea spray aerosol (SSA), respectively (Sellegri et al., 2008; Villani et al., 2013). In further support of this subdivision, the SSA aerosol comprised $7 \pm 2 \%$ of the observed number concentration of $100 \mathrm{~nm}$ particles, which is consistent with the total proportion of SSA reported by Quinn et al. (2017) at similar latitudes. There was no apparent difference in volatility at $120^{\circ} \mathrm{C}$, with a universal $12 \pm 2 \%$ reduction in particle volume; however, this increased their HGFs to $1.61 \pm 0.02$ and $2.01 \pm 0.05$, respectively (Table 2). The difference between the volume and mass fractions which remained after heating imply the presence of a substantial volume of refractory material (such as SSA) which could not be efficiently detected by the AMS.

The hygroscopic contribution of the semi-volatile component was estimated from its mean composition using Eq. (4), assuming a simple mixture of sulfuric acid and OA. The corresponding parameters are listed in Table 1, where the OA HGF has been determined from an $\mathrm{O}: \mathrm{C}$ - HGF parame- terisation (Massoli et al., 2010). This compositional model gave a semi-volatile HGF of $1.13 \pm 0.05$. Applying the same model to direct VH-TDMA measurements of the nss sulfate aerosol yielded a semi-volatile HGF of $1.2 \pm 0.3$ in agreement with the composition-based estimate.

Since both the SSA and nss sulfate aerosol shared similar volatilities, their semi-volatile components may likewise have shared similar composition and hygroscopic contributions. Based on the VH-TDMA measurements of heated SSA HGF and the above semi-volatile HGF, the model predicted an unheated SSA HGF of $1.94 \pm 0.05$. This is in line with the observed value and strongly suggests that both aerosol types had accumulated similar semi-volatile sulfates and OA during their atmospheric lifetimes.

\section{Conclusions}

A new sampling system has been developed which pairs a VH-TDMA and an AMS to obtain simultaneous measurements of hygroscopicity, volatility and composition. By cycling both instruments between heated and unheated sampling lines, properties of the semi-volatile fraction can be directly measured in near real time, over a range of preselected diameters, TD temperatures and humidities. Size- and temperature-dependent transmission efficiencies have been characterised for the two sampling lines and relative losses of up to $15 \%$ are observed in the TD line at $120^{\circ} \mathrm{C}(50 \mathrm{~nm}$, $\mathrm{AS})$.

Two measurement campaigns have been discussed which presented distinctly different and challenging sampling conditions. The capacity of both instruments to perform sizeresolved measurements allowed size dependencies to be identified and targeted in the analysis of the chamber-based campaign. However this requirement for size-dependent composition restricted analysis to a small subset of the total aerosol mass. In addition, the rapid SOA formation required a reasonably high time resolution to capture the progressive impact on composition and hygroscopicity. Although these constraints led to limited signal averaging and elevated detection limits, the independent composition-based HGF estimates demonstrated consistent agreement with direct VH-TDMA measurements. The $\mathrm{O}: \mathrm{C}$ ratio of the LVOA offered a reasonable estimate of its hygroscopic contribution. However, direct VH-TDMA measurements indicated that the HGF contribution of the SVOA component was markedly lower, despite having a very similar $\mathrm{O}: \mathrm{C}$ ratio to LVOA. This may further support the conclusion that these parameters are not well correlated, as reported by Hildebrandt Ruiz et al. (2015), and demonstrates the benefit of the complementary hygroscopic, volatility and compositional measurements offered by the combined sampling system.

In contrast to the chamber experiment, aerosol number and mass concentrations were very low during the marine atmospheric measurements, but by averaging across the full 
$6 \mathrm{~h}$ period and using bulk compositional measurements, the two instruments obtained meaningful measurements consistent with characteristic marine aerosol properties. The distribution of HGFs in the marine aerosol revealed an external mixture of nss sulfates and SSA. From these, an internally mixed semi-volatile fraction was separated and attributed to sulfuric acid and an OA component with a low degree of oxidation $(\mathrm{O}: \mathrm{C}=0.24)$. Finally, hygroscopic modelling supported the assumption that this semi-volatile component was common to both aerosol types.

In summary, these findings demonstrate that the combined system is well suited to analysing complex mixed aerosols and directly linking the composition of volatility-separated components to their hygroscopic contribution. If suitable sampling parameters and analytical methods are carefully chosen, the approach is resilient to low concentrations, sizedependent compositions or rapidly evolving aerosol properties. It is hoped that future measurements using this method will help improve models of aerosol-cloud interactions, particularly in regions subject to high levels of volatile organic emissions or mixed aerosols from diverse sources.

Data availability. The underlying research data can be accessed upon request to the corresponding author (Zoran Ristovski, z.ristovski@qut.edu.au).

\section{The Supplement related to this article is available online at https://doi.org/10.5194/amt-11-4361-2018-supplement.}

Author contributions. JA operated the instrumentation, analysed and interpreted the data and prepared the manuscript. LC assisted with the operation of the VH-TDMA and contributed to data analysis and interpretation. MM assisted with the operation of the VHTDMA and AMS, and contributed to data interpretation and writing. ZDR contributed to the campaign organisation, data interpretation and writing, and supervised the work of Joel Alroe. BM contributed to the campaign organisation, data interpretation and writing, and supervised the work of Joel Alroe. CO assisted with operating the smog chamber and contributed to the data analysis. GJ contributed to data interpretation and writing, and supervised the work of Joel Alroe.

Competing interests. The authors declare that they have no conflict of interest.

Acknowledgement. This work was funded by an Australian Government Research Training Program Scholarship and an ARC Discovery grant (DP150101649). The authors would like to acknowledge and thank the Cape Grim Baseline Air Pollution Station staff for providing on-site support and meteorological data, and Alastair Williams from the Australian Nuclear Science and Technology Organisation for associated radon-222 measurements.

Edited by: Francis Pope

Reviewed by: two anonymous referees

\section{References}

An, W. J., Pathak, R. K., Lee, B.-H., and Pandis, S. N.: Aerosol volatility measurement using an improved thermodenuder: Application to secondary organic aerosol, J. Aerosol Sci, 38, 305314, https://doi.org/10.1016/j.jaerosci.2006.12.002, 2007.

Andreae, M. O. and Rosenfeld, D.: Aerosol-cloudprecipitation interactions. Part 1 . The nature and sources of cloud-active aerosols, Earth-Sci. Rev., 89, 13-41, https://doi.org/10.1016/j.earscirev.2008.03.001, 2008.

Ault, A. P., Moffet, R. C., Baltrusaitis, J., Collins, D. B., Ruppel, M. J., Cuadra-Rodriguez, L. A., Zhao, D., Guasco, T. L., Ebben, C. J., Geiger, F. M., Bertram, T. H., Prather, K. A., and Grassian, V. H.: Size-Dependent Changes in Sea Spray Aerosol Composition and Properties with Different Seawater Conditions, Environ. Sci. Technol., 47, 5603-5612, https://doi.org/10.1021/es400416g, 2013.

Bahreini, R., Dunlea, E. J., Matthew, B. M., Simons, C., Docherty, K. S., DeCarlo, P. F., Jimenez, J. L., Brock, C. A., and Middlebrook, A. M.: Design and Operation of a PressureControlled Inlet for Airborne Sampling with an Aerodynamic Aerosol Lens, Aerosol Sci. Technol., 42, 465-471, https://doi.org/10.1080/02786820802178514, 2008.

Barmet, P., Dommen, J., DeCarlo, P. F., Tritscher, T., Praplan, A. P., Platt, S. M., Prévôt, A. S. H., Donahue, N. M., and Baltensperger, U.: $\mathrm{OH}$ clock determination by proton transfer reaction mass spectrometry at an environmental chamber, Atmos. Meas. Tech., 5, 647-656, https://doi.org/10.5194/amt-5-647-2012, 2012.

Cain, K. P. and Pandis, S. N.: A technique for the measurement of organic aerosol hygroscopicity, oxidation level, and volatility distributions, Atmos. Meas. Tech., 10, 4865-4876, https://doi.org/10.5194/amt-10-4865-2017, 2017.

Canagaratna, M. R., Jimenez, J. L., Kroll, J. H., Chen, Q., Kessler, S. H., Massoli, P., Hildebrandt Ruiz, L., Fortner, E., Williams, L. R., Wilson, K. R., Surratt, J. D., Donahue, N. M., Jayne, J. T., and Worsnop, D. R.: Elemental ratio measurements of organic compounds using aerosol mass spectrometry: characterization, improved calibration, and implications, Atmos. Chem. Phys., 15, 253-272, https://doi.org/10.5194/acp-15-253-2015, 2015.

Cerully, K. M., Bougiatioti, A., Hite Jr., J. R., Guo, H., Xu, L., Ng, N. L., Weber, R., and Nenes, A.: On the link between hygroscopicity, volatility, and oxidation state of ambient and water-soluble aerosols in the southeastern United States, Atmos. Chem. Phys., 15, 8679-8694, https://doi.org/10.5194/acp15-8679-2015, 2015.

Chen, X. and Hopke, P. K.: Secondary organic aerosol from $\alpha$ pinene ozonolysis in dynamic chamber system, Indoor Air 19, 335-345, https://doi.org/10.1111/j.1600-0668.2009.00596.x, 2009.

Cocker III, D. R., Clegg, S. L., Flagan, R. C., and Seinfeld, J. H.: The effect of water on gas-particle partitioning of secondary organic aerosol. Part I: $\alpha$-pinene/ozone system, Atmos. Environ., 
35, 6049-6072, https://doi.org/10.1016/S1352-2310(01)004046, 2001.

DeCarlo, P. F., Slowik, J. G., Worsnop, D. R., Davidovits, P., and Jimenez, J. L.: Particle Morphology and Density Characterization by Combined Mobility and Aerodynamic Diameter Measurements. Part 1: Theory, Aerosol Sci. Technol., 38, 1185-1205, https://doi.org/10.1080/027868290903907, 2004.

DeCarlo, P. F., Kimmel, J. R., Trimborn, A., Northway, M. J., Jayne, J. T., Aiken, A. C., Gonin, M., Fuhrer, K., Horvath, T., Docherty, K. S., Worsnop, D. R., and Jimenez, J. L.: Field-Deployable, High-Resolution, Time-ofFlight Aerosol Mass Spectrometer, Anal. Chem., 78, 8281-8289, https://doi.org/10.1021/ac061249n, 2006.

Denjean, C., Formenti, P., Picquet-Varrault, B., Pangui, E., Zapf, P., Katrib, Y., Giorio, C., Tapparo, A., Monod, A., Temime-Roussel, B., Decorse, P., Mangeney, C., and Doussin, J. F.: Relating hygroscopicity and optical properties to chemical composition and structure of secondary organic aerosol particles generated from the ozonolysis of $\alpha$-pinene, Atmos. Chem. Phys., 15, 3339-3358, https://doi.org/10.5194/acp-15-3339-2015, 2015.

Denkenberger, K. A., Moffet, R. C., Holecek, J. C., Rebotier, T. P., and Prather, K. A.: Real-Time, Single-Particle Measurements of Oligomers in Aged Ambient Aerosol Particles, Environ. Sci. Technol., 41, 5439-5446, https://doi.org/10.1021/es0703291, 2007.

Donahue, N. M., Kroll, J. H., Pandis, S. N., and Robinson, A. L.: A two-dimensional volatility basis set - Part 2: Diagnostics of organic-aerosol evolution, Atmos. Chem. Phys., 12, 615-634, https://doi.org/10.5194/acp-12-615-2012, 2012.

Drewnick, F., Hings, S. S., DeCarlo, P., Jayne, J. T., Gonin, M., Fuhrer, K., Weimer, S., Jimenez, J. L., Demerjian, K. L., Borrmann, S., and Worsnop, D. R.: A New Time-of-Flight Aerosol Mass Spectrometer (TOF-AMS) - Instrument Description and First Field Deployment, Aerosol Sci. Technol., 39, 637-658, https://doi.org/10.1080/02786820500182040, 2005.

Duplissy, J., Gysel, M., Alfarra, M. R., Dommen, J., Metzger, A., Prevot, A. S. H., Weingartner, E., Laaksonen, A., Raatikainen, T., Good, N., Turner, S. F., McFiggans, G., and Baltensperger, U.: Cloud forming potential of secondary organic aerosol under near atmospheric conditions, Geophys. Res. Lett., 35, L03818, https://doi.org/10.1029/2007GL031075, 2008.

Dusek, U., Frank, G. P., Hildebrandt, L., Curtius, J., Schneider, J., Walter, S., Chand, D., Drewnick, F., Hings, S., Jung, D., Borrmann, S., and Andreae, M. O.: Size matters more than chemistry for cloud-nucleating ability of aerosol particles, Science, 312, 137-1378, https://doi.org/10.1126/science.1125261, 2006.

Fletcher, C. A., Johnson, G. R., Ristovski, Z. D., and Harvey, M.: Hygroscopic and volatile properties of marine aerosol observed at Cape Grim during the P2P campaign, Environ. Chem., 4, 162171, https://doi.org/10.1071/EN07011, 2007.

Hall, W. A. and Johnston, M. V.: The ThermalStability of Oligomers in Alpha-Pinene Secondary Organic Aerosol, Aerosol Sci. Technol., 46, 983-989, https://doi.org/10.1080/02786826.2012.685114, 2012.

Hersey, S. P., Sorooshian, A., Murphy, S. M., Flagan, R. C., and Seinfeld, J. H.: Aerosol hygroscopicity in the marine atmosphere: a closure study using high-time-resolution, multiple-RH DASHSP and size-resolved C-ToF-AMS data, Atmos. Chem. Phys., 9, 2543-2554, https://doi.org/10.5194/acp-9-2543-2009, 2009.
Hildebrandt Ruiz, L., Paciga, A. L., Cerully, K. M., Nenes, A., Donahue, N. M., and Pandis, S. N.: Formation and aging of secondary organic aerosol from toluene: changes in chemical composition, volatility, and hygroscopicity, Atmos. Chem. Phys., 15, 83018313, https://doi.org/10.5194/acp-15-8301-2015, 2015.

Hong, J., Häkkinen, S. A. K., Paramonov, M., Äijälä, M., Hakala, J., Nieminen, T., Mikkilä, J., Prisle, N. L., Kulmala, M., Riipinen, I., Bilde, M., Kerminen, V. M., and Petäjä, T.: Hygroscopicity, $\mathrm{CCN}$ and volatility properties of submicron atmospheric aerosol in a boreal forest environment during the summer of 2010, Atmos. Chem. Phys., 14, 4733-4748, https://doi.org/10.5194/acp14-4733-2014, 2014.

Hoppel, W. A., Frick, G. M., and Larson, R. E.: Effect of nonprecipitating clouds on the aerosol size distribution in the marine boundary layer, Geophys. Res. Lett., 13, 125-128, https://doi.org/10.1029/GL013i002p00125, 1986.

Huffman, J. A., Ziemann, P. J., Jayne, J. T., Worsnop, D. R., and Jimenez, J. L.: Development and Characterization of a FastStepping/Scanning Thermodenuder for Chemically-Resolved Aerosol Volatility Measurements, Aerosol Sci. Technol., 42, 395-407, https://doi.org/10.1080/02786820802104981, 2008.

Huffman, J. A., Docherty, K. S., Aiken, A. C., Cubison, M. J., U1brich, I. M., DeCarlo, P. F., Sueper, D., Jayne, J. T., Worsnop, D. R., Ziemann, P. J., and Jimenez, J. L.: Chemically-resolved aerosol volatility measurements from two megacity field studies, Atmos. Chem. Phys., 9, 7161-7182, https://doi.org/10.5194/acp9-7161-2009, 2009.

Jimenez, J. L., Canagaratna, M. R., Donahue, N. M., Prevot, A. S. H., Zhang, Q., Kroll, J. H., DeCarlo, P. F., Allan, J. D., Coe, H., Ng, N. L., Aiken, A. C., Docherty, K. S., Ulbrich, I. M., Grieshop, A. P., Robinson, A. L., Duplissy, J., Smith, J. D., Wilson, K. R., Lanz, V. A., Hueglin, C., Sun, Y. L., Tian, J., Laaksonen, A., Raatikainen, T., Rautiainen, J., Vaattovaara, P., Ehn, M., Kulmala, M., Tomlinson, J. M., Collins, D. R., Cubison, M. J., E., Dunlea, J., Huffman, J. A., Onasch, T. B., Alfarra, M. R., Williams, P. I., Bower, K., Kondo, Y., Schneider, J., Drewnick, F., Borrmann, S., Weimer, S., Demerjian, K., Salcedo, D., Cottrell, L., Griffin, R., Takami, A., Miyoshi, T., Hatakeyama, S., Shimono, A., Sun, J. Y., Zhang, Y. M., Dzepina, K., Kimmel, J. R., Sueper, D., Jayne, J. T., Herndon, S. C., Trimborn, A. M., Williams, L. R., Wood, E. C., Middlebrook, A. M., Kolb, C. E., Baltensperger, U., and Worsnop, D. R.: Evolution of Organic Aerosols in the Atmosphere, Science, 326, 1525-1529, https://doi.org/10.1126/science.1180353, 2009.

Johnson, G. R., Ristovski, Z., and Morawska, L.: Method for measuring the hygroscopic behaviour of lower volatility fractions in an internally mixed aerosol, J. Aerosol Sci., 35, 443-455, https://doi.org/10.1016/j.jaerosci.2003.10.008, 2004.

Johnson, G. R., Ristovski, Z. D., D'Anna, B., and Morawska, L.: Hygroscopic behavior of partially volatilized coastal marine aerosols using the volatilization and humidification tandem differential mobility analyzer technique, J. Geophys. Res.-Atmos., 110, D20203, https://doi.org/10.1029/2004JD005657, 2005.

Knote, C., Brunner, D., Vogel, H., Allan, J., Asmi, A., Äijälä, M., Carbone, S., van der Gon, H. D., Jimenez, J. L., Kiendler-Scharr, A., Mohr, C., Poulain, L., Prévôt, A. S. H., Swietlicki, E., and Vogel, B.: Towards an online-coupled chemistry-climate model: evaluation of trace gases and aerosols in COSMO-ART, Geosci. 
Model. Dev, 4, 1077-1102, https://doi.org/10.5194/gmd-4-10772011, 2011.

Kroll, J. H., Donahue, N. M., Jimenez, J. L., Kessler, S. H., Canagaratna, M. R., Wilson, K. R., Altieri, K. E., Mazzoleni, L. R., Wozniak, A. S., Bluhm, H., Mysak, E. R., Smith, J. D., Kolb, C. E., and Worsnop, D. R.: Carbon oxidation state as a metric for describing the chemistry of atmospheric organic aerosol, Nat. Chem., 3, 133-139, https://doi.org/10.1038/nchem.948, 2011.

Liu, P. S. K., Deng, R., Smith, K. A., Williams, L. R., Jayne, J. T., Canagaratna, M. R., Moore, K., Onasch, T. B., Worsnop, D. R., and Deshler, T.: Transmission Efficiency of an Aerodynamic Focusing Lens System: Comparison of Model Calculations and Laboratory Measurements for the Aerodyne Aerosol Mass Spectrometer, Aerosol Sci. Technol., 41, 721-733, https://doi.org/10.1080/02786820701422278, 2007.

Mallet, M. D., Cravigan, L. T., Milic, A., Alroe, J., Ristovski, Z. D., Ward, J., Keywood, M., Williams, L. R., Selleck, P., and Miljevic, B.: Composition, size and cloud condensation nuclei activity of biomass burning aerosol from northern Australian savannah fires, Atmos. Chem. Phys., 17, 3605-3617, https://doi.org/10.5194/acp-17-3605-2017, 2017.

Massoli, P., Lambe, A. T., Ahern, A. T., Williams, L. R., Ehn, M., Mikkilä, J., Canagaratna, M. R., Brune, W. H., Onasch, T. B., Jayne, J. T., Petäjä, T., Kulmala, M., Laaksonen, A., Kolb, C. E., Davidovits, P., and Worsnop, D. R.: Relationship between aerosol oxidation level and hygroscopic properties of laboratory generated secondary organic aerosol (SOA) particles, Geophys. Res. Lett., 37, L24801, https://doi.org/10.1029/2010GL045258, 2010.

Meyer, N. K., Duplissy, J., Gysel, M., Metzger, A., Dommen, J., Weingartner, E., Alfarra, M. R., Prevot, A. S. H., Fletcher, C., Good, N., McFiggans, G., Jonsson, A. M., Hallquist, M., Baltensperger, U., and Ristovski, Z. D.: Analysis of the hygroscopic and volatile properties of ammonium sulphate seeded and unseeded SOA particles, Atmos. Chem. Phys., 9, 721-732, https://doi.org/10.5194/acp-9-721-2009, 2009.

Petters, M. and Kreidenweis, S.: A single parameter representation of hygroscopic growth and cloud condensation nucleus activity, Atmos. Chem. Phys., 7, 1961-1971, https://doi.org/10.5194/acp7-1961-2007, 2007.

Prenni, A. J., Petters, M. D., Kreidenweis, S. M., DeMott, P. J., and Ziemann, P. J.: Cloud droplet activation of secondary organic aerosol, J. Geophys. Res.-Atmos., 112, D10223, https://doi.org/10.1029/2006JD007963, 2007.

Quinn, P. K., Coffman, D. J., Johnson, J. E., Upchurch, L. M., and Bates, T. S.: Small fraction of marine cloud condensation nuclei made up of sea spray aerosol, Nat. Geosci., 10, 674-679, https://doi.org/10.1038/ngeo3003, 2017.

Raatikainen, T., Vaattovaara, P., Tiitta, P., Miettinen, P., Rautiainen, J., Ehn, M., Kulmala, M., Laaksonen, A., and Worsnop, D. R.: Physicochemical properties and origin of organic groups detected in boreal forest using an aerosol mass spectrometer, Atmos. Chem. Phys., 10, 2063-2077, https://doi.org/10.5194/acp10-2063-2010, 2010.

Riipinen, I., Pierce, J. R., Donahue, N. M., and Pandis, S. N.: Equilibration time scales of organic aerosol inside thermodenuders: Evaporation kinetics versus thermodynamics, Atmos. Environ., 44, 597-607, https://doi.org/10.1016/j.atmosenv.2009.11.022, 2010.
Saleh, R., Shihadeh, A., and Khlystov, A.: On transport phenomena and equilibration time scales in thermodenuders, Atmos. Meas. Tech., 4, 571-581, https://doi.org/10.5194/amt-4571-2011, 2011.

Seinfeld, J. H. and Pandis, S. N.: Atmospheric Chemistry and Physics: From Air Pollution to Climate Change, 3 ed., John Wiley \& Sons, Inc., New York, 719-720, 2016.

Seinfeld, J. H. and Pankow, J. F.: Organic Atmospheric Particulate Material, Annu. Rev. Phys. Chem., 54, 121-140, https://doi.org/10.1146/annurev.physchem.54.011002.103756, 2003.

Sellegri, K., Villani, P., Picard, D., Dupuy, R., O'Dowd, C., and Laj, P.: Role of the volatile fraction of submicron marine aerosol on its hygroscopic properties, Atmos. Res., 90, 272-277, https://doi.org/10.1016/j.atmosres.2008.04.004, 2008.

Stokes, R. H. and Robinson, R. A.: Interactions in Aqueous Nonelectrolyte Solutions. I. Solute-Solvent Equilibria, J. Phys. Chem., 70, 2126-2131, https://doi.org/10.1021/j100879a010, 1966.

Takegawa, N., Miyakawa, T., Watanabe, M., Kondo, Y., Miyazaki, Y., Han, S., Zhao, Y., van Pinxteren, D., Bruggemann, E., Gnauk, T., Herrmann, H., Xiao, R., Deng, Z., Hu, M., Zhu, T., and Zhang, Y.: Performance of an Aerodyne Aerosol Mass Spectrometer (AMS) during Intensive Campaigns in China in the Summer of 2006, Aerosol Sci. Technol., 43, 189-204, https://doi.org/10.1080/02786820802582251, 2009.

Timko, M. T., Yu, Z., Kroll, J., Jayne, J. T., Worsnop, D. R., Miake-Lye, R. C., Onasch, T. B., Liscinsky, D., Kirchstetter, T. W., Destaillats, H., Holder, A. L., Smith, J. D., and Wilson, K. R.: Sampling Artifacts from Conductive Silicone Tubing, Aerosol Sci. Technol., 43, 855-865, https://doi.org/10.1080/02786820902984811, 2009.

Varutbangkul, V., Brechtel, F. J., Bahreini, R., Ng, N. L., Keywood, M. D., Kroll, J. H., Flagan, R. C., Seinfeld, J. H., Lee, A., and Goldstein, A. H.: Hygroscopicity of secondary organic aerosols formed by oxidation of cycloalkenes, monoterpenes, sesquiterpenes, and related compounds, Atmos. Chem. Phys., 6, 23672388, https://doi.org/10.5194/acp-6-2367-2006, 2006.

Villani, P., Sellegri, K., Monier, M., and Laj, P.: Influence of semivolatile species on particle hygroscopic growth, Atmos. Environ., 79, 129-137, https://doi.org/10.1016/j.atmosenv.2013.05.069, 2013.

Virkkula, A., Van Dingenen, R., Raes, F., and Hjorth, J.: Hygroscopic properties of aerosol formed by oxidation of limonene, $\alpha$-pinene, and $\beta$-pinene, J. Geophys. Res.-Atmos., 104, 35693579, https://doi.org/10.1029/1998JD100017, 1999.

Washburn, E. W. (Ed.): International Critical Tables of Numerical Data, Physics, Chemistry and Technology, 1 ed., Vol. 1, McGraw-Hill, New York, p. 107, 1926.

Wex, H., McFiggans, G., Henning, S., and Stratmann, F.: Influence of the external mixing state of atmospheric aerosol on derived CCN number concentrations, Geophys. Res. Lett., 37, L10805, https://doi.org/10.1029/2010GL043337, 2010.

Xiong, J. Q., Zhong, M., Fang, C., Chen, L. C., and Lippmann, M.: Influence of Organic Films on the Hygroscopicity of Ultrafine Sulfuric Acid Aerosol, Environ. Sci. Technol., 32, 3536-3541, https://doi.org/10.1021/es980019q, 1998. 